\title{
Technology, Demographic Characteristics and E-Learning Acceptance: A Conceptual Model Based on Extended Technology Acceptance Model
}

\author{
Ali Tarhini ${ }^{1}$, Tariq Elyas ${ }^{2}$, Mohammad Ali Akour ${ }^{3} \&$ Zahran Al-Salti ${ }^{4}$ \\ ${ }^{1}$ Department of Information Systems, Sultan Qaboos University, Mascut, Sultanate of Oman \\ ${ }^{2}$ English Language Institute, King Abdulaziz University, Jeddah, Saudi Arabia \\ ${ }^{3}$ Department of Management Information Systems, Al'Sharqiyah University, Ibra, Sultanate of Oman \\ ${ }^{4}$ Department of Information Systems, Sultan Qaboos University, Mascut, Sultanate of Oman \\ Correspondence: Ali Tarhini, Department of Information Systems, Sultan Qaboos University, Mascut, Sultanate \\ of Oman. Tel: 974-5-012-1922. E-mail: ali.tarhini@hotmail.co.uk
}

Received: June 30, 2016

Accepted: July 16, 2016

Online Published: July 26, 2016

doi:10.5539/hes.v6n3p72

URL: http://dx.doi.org/10.5539/hes.v6n3p72

\begin{abstract}
The main aim of this paper is to develop an amalgamated conceptual model of technology acceptance that explains how individual, social, cultural and organizational factors affect the students' acceptance and usage behaviour of the Web-based learning systems. More specifically, the proposed model extends the Technology Acceptance Model (TAM) to include four constructs namely, Quality of work life; Social Norm; Facilitating Conditions and self-efficacy. In addition, Individual differences - namely, age, gender, and experience - are hypothesized to moderate the effects of these constructs on behavioral intention and technology use. A comprehensive understanding of this model will provide valuable insights into the factors that influence the acceptance or resistance of web-based learning system by intended users and offers opportunities for future research in understanding the acceptance of technology. Further, understanding these variables is helpful for instructors to design meaningful educational activities to promote student knowledge construction and make learning more effective and appealing.
\end{abstract}

Keywords: technology acceptance model, e-learning, individual differences, information technology, learning management systems

\section{Introduction}

The development of Information and Communication Technologies (ICTs) has provided educators and learners with an innovative learning environment to stimulate and enhance the teaching and learning process (El-Masri \& Tarhini, 2015; Yadav et al., 2016). Many higher educational institutions and universities around the world are investing heavily to equip themselves with e-learning tools to support their traditional learning and teaching because of its flexibility, low cost and convenience (Deng \& Tavares, 2013; Esterhuyse \& Scholtz, 2015a). By using e-learning tools such as web-based learning systems, the students will be able to download learning content, submit assignments, and interact with their instructors and other colleagues (Piña, 2010; Abu-Shanab, 2014).

Despite the perceived advantages of e-learning tools mentioned above, previous research has shown that the students are not fully utilized its importance (Álvarez et al., 2013; Tarhini, Hone, \& Liu, 2013a). In other words, if the students refuse to use the system, then it will boom to failure (McGill, Klobas, \& Renzi, 2014; Scholtz et al., 2014). For instance, Lam et al. (2012) examined the acceptance of e-learning by undergraduate students and found out that only $14.8 \%$ of the students used related features for online discussion. Another study conducted by Islam (2013) in Finland, the author found that the students were mainly using the web-based learning system to download their course materials and submitting their assignments only. Furthermore, recent studies have shown that web-based learning system implementation is not simply a technological solution but also a process of many different factors, such as social factors (Tarhini, Hone, \& Liu, 2014b; Aparicio, Bacao, \& Oliveira; 2016), organizational such as Facilitating Conditions (FCs) (Masa'deh et al., 2016) and individual factors such 
as computer efficacy (Liaw, 2008; Tarhini, Hone, \& Liu, 2016) in addition to behavioural and cultural factors. Such major factors play an important role in how the system is developed and used (Zhang, Zhao, \& Tan, 2008; Abu-Shanab, Momani, \& Ababneh, 2012). Thus, it becomes imperative to understand the factors that may hinder or enable the acceptance of web-based learning systems by students in order to enhance the quality of learning and teaching activities.

In the technology acceptance and adoption literature, a considerable number of models have been applied (e.g., the Theory of Reasoned Action (TRA), the Theory of Planned Behaviour (TPB) and the Technology Acceptance Model (TAM), Unified Theory of Acceptance and Use of Technology (UTAUT)) to investigate and explore the determinants of user's behaviour towards adoption and using information technology. Among these models, the Technology Acceptance Model (TAM) (Davis, 1989) is the most frequently cited and influential model for explaining technology acceptance and adoption. Since it has been developed, TAM has been extensively used, tested, and extended to explain technology adoption and success in a number of application areas (e.g., Bagozzi, 2007; Yousafzai, Foxall, \& Pallister, 2007a; Venkatesh \& Bala, 2008) and e-learning (Sharma \& Chandel, 2013; Park, Nam, \& Cha, 2012). Therefore, this paper aims to explain and discuss the development of a conceptual model of technology acceptance that shows how individual, social, cultural and organizational factors affect the students' acceptance and usage behaviour of the Web-based learning systems. More specifically, the proposed model extends the Technology Acceptance Model (TAM) to include four constructs namely, Quality of work life; Social Norm; Facilitating Conditions and self-efficacy. In addition, Individual differences - namely, age, gender, and experience - are hypothesized to moderate the effects of these constructs on behavioral intention and technology use. A comprehensive understanding of this model will provide valuable insights into the factors that influence the acceptance or resistance of web-based learning system by intended users and offers opportunities for future research in understanding the acceptance of technology. Further, understanding these variables is helpful for instructors to design meaningful educational activities to promote student knowledge construction and make learning more effective and appealing.

\section{Theoretical Framework}

This paper will identify a set of factors that fall in different domains such as personal, social, behavioural and technological that might influence the use and adoption of e-learning systems. We discuss the development of the proposed conceptual model for future research by explaining the different factors in greater details. It is worth noting that the proposed model is trying to obtain a complete understanding of a phenomenon under investigation which requires some sacrifice in the degree of parsimony (Taylor \& Todd, 1995b). The development of the proposed model help future researchers to hypothesis and test the relationships between the identified constructs in order to check if the theorized model is valid or not (Sekaran \& Bougie, 2011). However, drawing on the fact that prior models related to acceptance and adoptions of IT have some limitations, therefore, the most appropriate approach was to select the relevant constructs related to context of e-learning.

In particular, the proposed research model will integrate 3 categories of variables. The first category includes the key determinants (independent variables) that may have an effect on Behavioural Intention (BI) and Actual Usage (AU) of the e-learning system. These constructs are Perceived Ease of Use (PEU), Perceived Usefulness (PU), Social Norms (SN), Facilitating Conditions (FC), Self-efficacy (SE) and Quality of Work Life (QWL). The second category includes two dependent variables which are BI and $\mathrm{AU}$. In this paper BI is expected to influence the AU of the e-learning system. The third category integrates a set of demographic variables (age, gender, educational level and experience) as moderators that may have an impact on the relationships between the key determinants and BI. Figure 1 depicts the proposed conceptual model and a detailed explanation of each category is presented in the next sections of this paper. 


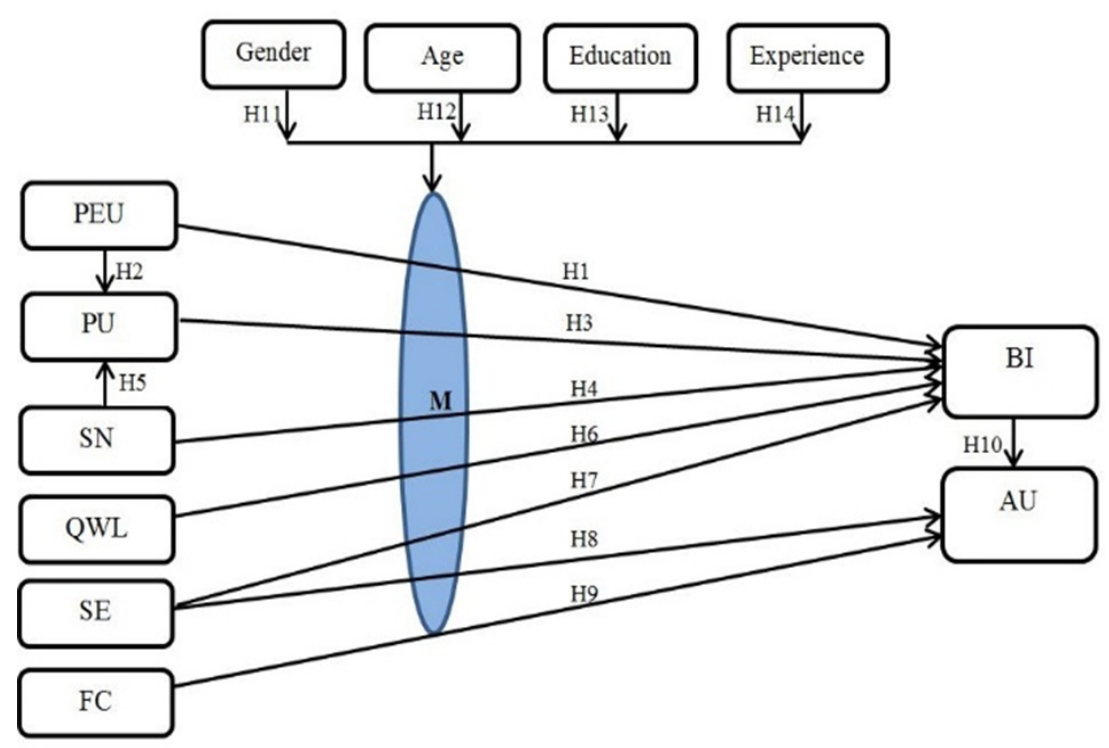

Figure 1. The proposed conceptual model

\subsection{Perceived Ease of Use}

Perceived Ease of Use (PEU) is defined as "the degree to which a person believes that using a particular system would be free of effort" (Davis, Bagozzi, \& Warshaw, 1989, p. 320) and is similar to effort expectancy in UTAUT (Venkatesh et al., 2003). In the TAM, TAM2 and DTPB, PEU was theorized as a direct determinant of BI. In addition, a number of researchers found a support to the indirect relationship of PEU on BI through PU (Yousafzai et al., 2007a; Almajali et al., 2016; Al-Tomny et al., 2016; Ramirez-Anormaliza et al., 2016; Alalwan et al., 2016). Strong evidence supported the important role that PEU play in predicting the BI (Davis, 1989; Igbaria et al., 1997; Tarhini, Hone, \& Liu, 2014a; Masa'deh et al., 2015; Abdullah \& Ward, 2016; Esterhuyse \& Scholtz, 2016).

Reviewing the literature, the majority of the subsequent studies about student perceptions on using technologies support the important role that PEU plays in predicting the BI (Liu et al., 2010; Chang \& Tung, 2008; Harb \& Abu-Shanab, 2012; Anormaliza et al., 2015). However, the degree of significance was different between the findings in the literature. The difference in the findings was based on the field of study, sample size, or techniques used for analyzing. For example, Peng et al. (2009) found that PEU was the strongest determinant on the intention to use the system, which supported the findings of Chang and Tung's (2008) study. Furthermore, Saeed and Abdinnour-Helm (2008) found that PEU have a direct and significant influence on BI. However, it was not the strongest predictor on the BI to use to the system. In contrast, Chesney (2006) concluded that perceived ease of use did not have a direct and significant influence on the intention to use the system.

Therefore, the inclusion of PEU is to investigate students' beliefs of whether the system is free of effort and to predict their behavioural intention to use the e-learning systems. It is expected that if the students find the system easy to use, then they are more likely to adopt and use it. Hence, based on many models and previous research that consider the direct relationship of PEU on BI and indirectly through PU, we propose the following hypothesis:

H1: Perceived Ease of Use will have a direct positive influence on the intention to use web-based learning System.

H2: Perceived Ease of Use will have a direct positive influence on Perceived Usefulness of web-based learning system.

\subsection{Perceived Usefulness}

Perceived Usefulness (PU) is defined as "the degree to which a person believes that using a particular system would enhance his/her job performance" (Davis, 1989, p. 453). PU is similar to relative advantage in the model DOI and performance expectancy in UTAUT (Venkatesh et al., 2003). In other words, it is the extent to which 
benefits are seen as outweighing costs. In the TAM, TAM2 and Augmented TAM, PU was theorized as a direct determinant of BI. In addition, many researchers have provided evidence of its direct determinant on AU (Gefen \& Straub, 1997; Igbaria, Parasuraman, \& Baroudi, 1996; Lederer et al., 2000; Szajna, 1994; Alenezi et al., 2015; Alalwan et al., 2016; Abdullah, Ward, \& Ahmed, 2016; Masa'deh et al., 2016; Obeidat et al., 2016). Compared to the other behavioural belief construct (PEU), PU was found to have a significantly greater correlation with BI than did perceived ease of use (Davis, 1989) and the same result has been found in e-learning studies (Liu et al., 2010; Chang \& Tung, 2008). Davis (1989) concluded that users are mostly driven to adopt and use the system primarily because of the functions it performs for them.

In the present context of the paper, PU will be used to investigate the students' beliefs about the potential benefits in using the elearning system. Many research studies have highlighted the important rule that PU plays on BI to use Web-based learning tools (Chang \& Tung, 2008; Liu et al., 2010). For example, Liu et al. (2010) applied an extended TAM to explore the factors that affect the intention to use an online learning community. They found that PU was the most influential variable in predicting the intention to use the web-based learning system. In contrast, Saeed (2008) found that PU has an influence on the intention to use but was not the most influential factor. Therefore, it is expected that if students think that the e-learning system is useful and will add value to their education then they are more likely to adopt and use the system. In contrast, students may resist educational technologies if they are sceptical of their educational value. Therefore, it is hypothesized that PU will have a positive significant influence on the intention to use the elearning system. Therefore, the researcher hypothesized:

H3: Perceived Usefulness (PU) will have a direct positive influence on the intention to use web-based learning system.

\subsection{Social Norm}

Social norm also known as Social Influence, is defined as "the person's perception that most people who are important to him or her think he or she should or should not perform the behaviour in question" (Ajzen, 1991). In other words, $\mathrm{SN}$ refers to the social pressure coming from external environment which surrounds the individuals and may affect their perceptions and behaviours of engaging in a certain action (Ajzen, 1991, p. 188). SN was included in many theories such as TRA, TPB, DTPB and TAM2 and is similar to social influence in UTAUT; and image in IDT.

SN was studied in some research as an antecedent of BI and in other studies as an antecedent PU. However, as mentioned by Venkatesh et al. (2003) the influence of SN is very complex. SN was found to be an important determinant of behaviour in TRA and TPB, and directly and significantly related to the behavioural intention (Venkatesh et al., 2003; Venkatesh \& Morris, 2000; Alenezi et al., 2015a). The direct effect of SN on BI is justified from the fact that people may be influenced by the opinion of others and thus involved in certain behaviour even if they don't want to. Venkatesh and Davis (2000) argue that the effect of SN occurs only in mandatory environments and has less influence in a voluntary environment.

According to Taylor and Todd (1995b), SN is decomposed into two groups and usually determined by peer and superior influences. In the context of e-learning technologies, student's decision to adopt and accept such technologies is usually influenced by other colleagues/students and superiors/lecturers pressures (Sharma et al., 2014; Abbasi et al., 2015). However, there are inconsistencies in the findings when studying the direct impact of $\mathrm{SN}$ on BI. For example, while some scholars found a significant influence of SN on BI such as (Abbasi et al., 2015; Van Raaij \& Schepers, 2008; Almajali, Masa'deh, \& Al-Lozi, 2016) others failed to find any influence (Lewis, Agarwal, \& Sambamurthy, 2003; Chau \& Hu, 2002; Ndubisi, 2006; Davis, 1989). Davis (1989) omitted the SN construct from the original TAM due to theoretical and measurement problems, however SN was added later in TAM2 due to its importance in explaining the external influence of others on the behaviour of an individual. Therefore, based on the inconsistencies of the above findings and the importance of SN in establishing behavioural intention towards adoption and acceptance of a technology and its impact on PU, and in an attempt to overcome the limitation of TAM in measuring the influence of social environments (Venkatesh \& Davis, 2000), it is hypothesized:

H4: Social Norm will have a positive influence on student's behavioural intention to use and accept the e-learning technology.

H5: SN will have a positive influence on perceived usefulness of web-based learning system. 


\subsection{Quality of Work Life (QWL)}

The Quality of Work Life (QWL) seeks to achieve integration among technological, human, and societal demands (Cascio \& McEvoy, 2003). Reviewing the literature, the term "Quality of Work Life" has appeared in Research Journals in USA only in 1970s and since then it regained an interest by scholars and researchers. Quality of Life (QWL) was included based on a number of suggestions in the IS literature that this extension may improve the TAM model (Kripanont, 2007; Agarwal \& Karahanna, 2000).

QWL has not previously been considered within an educational context and the current study therefore explores whether it plays a role within this context. In this research, QWL is defined in terms of students' perception and belief that using the e-learning system will improve their quality of work life such as saving expenses when downloading e-journals, or in communication when using email to communicate with their instructors and colleagues. Generally speaking, a mismatch between students and the impact of technology on their lives can be disadvantageous for both students and institutions and which in turn affect their behavioural intention to use the e-learning systems. Thus, the emphasis is given to QWL construct due to the economic gains and increases in opportunities for advancement in students' lives and it is expected that the higher the QWL the better the acceptance of the technology.

Srite and Karahnana (1999) found a moderating effect of a set of individual differences including gender and culture on the relationship between QWL and behavioural intention. They found that people with high masculinity will focus more on materiality and might be concerned with usefulness and work goals rather than perceived ease of use and quality of work life that is dominated in the feminine cultures. Therefore, it is expected that introducing the QWL construct will enable a better capturing of cultural influence on the acceptance of e-learning systems especially the impact of masculinity/femininity on intention to use the system. According to Zakour (2004), the include of QWL in TAM will help in better understanding the technology acceptance by users and conclude that future research should highly consider this construct due to its importance. Thus, we propose that understanding the relationship between QWL and BI is an important goal, in order to satisfy the various needs of the students and in return eliciting favourable behavioural intention. It is worth noting that QWL can be considered the operationalize construct of PU. We therefore expect the relationship between those two constructs to be correlated. Based on previous discussions, we hypothesis the followings:

H6: QWL will have a positive influence on student's behavioural intention to use the web-based learning system.

\subsection{E-Learning and Self-Efficacy}

Self-Efficacy (SE)as an internal individual factor-has been defined as the belief "in one's capabilities to organize and execute the courses of action required to produce given attainments" (Bandura, 1997, p. 3). In the Social Cognitive Theory (SCT), SE is a type of self-assessment that helps the understanding of human behaviour and performance in a certain tasks (Bandura, 1997; Bandura, 1995; Alenezi et al., 2015b; Alalwan et al., 2015). In the context of IT, self-efficacy has been defined as "an individual's perceptions of his or her ability to use computers in the accomplishment of a task rather than reflecting simple component skills" (Compeau \& Higgins, 1995, p. 192).

According to Marakas et al. (1998), SE is categorized into two types, the first is related to general use of computers and is known as "general computer self-efficacy", whereas the second is related to a specific task on the computer and is known as "task-specific computer self-efficacy". Several studies have found SE to be an important determinant that directly influences the user's behavioural intention and actual usage of IT (Downey, 2006; Shih \& Fang, 2004; Guo \& Barnes, 2007; Yi \& Hwang, 2003; Hernandez, Jimenez, \& Jose Martin, 2009) and e-learning acceptance (Chang \& Tung, 2008; Yuen \& Ma, 2008; Park, 2009; Vijayasarathy, 2004; Chatzoglou et al., 2009; Roca, Chiu, \& Martínez, 2006; Darawsheh et al., 2016). On the contrary, Venkatesh et al. (2003) did not find a casual direct relationship between SE and BI.

In the context of this paper, self-efficacy is defined as a student's self-confidence in his or her ability to perform certain learning tasks using the e-learning system. In general, it is expected that e-learning users with higher level of self-efficacy are more likely to be more willing to adopt and use the system than those with lower self-efficacy. Therefore, consistent with previous research that integrated self-efficacy as a direct predictor that has effects on behavioural intention and actual usage of the system, we propose the following hypotheses:

H7: Computer self-efficacy will have a positive influence on student's behavioural intention to use the web-based learning system.

H8: Computer self-efficacy will have a positive influence on the actual usage of the web-based learning system. 


\subsection{Facilitating Conditions}

The Facilitating Condition (FC) has been defined as "the degree to which an individual believes that an organizational and technical infrastructure exists to support use of the system" (Venkatesh et al., 2003, p. 453). More specifically, it comprises the availability of external resources (time, money and effort), which is known in the literature as Resource Facilitating Conditions "RFC" (Fu, Farn, \& Chao, 2006; Lin, 2006; Guo \& Barnes, 2007; Ajjan \& Hartshorne, 2008) and also the availability of the technological resources (PCs, broadband, accessible network, network security, etc.), which is referred to as the Technology Facilitating Conditions "TFC" (Fu et al., 2006; Taylor \& Todd, 1995b). In other words, it is providing the external resources that are needed to facilitate the performance of a particular behaviour (Ajzen, 1985). In the context of e-learning, FC will be measured by the perception of students of whether they are able to access the required resources and the necessary support to use the e-learning services.

Reviewing the literature, FC construct is considered an important antecedent of the UTAUT model and is similar to Perceived Behavioural Control (PBC) from TPB, C-TAM/TPB and compatibility from IDT (Ajzen, 1985; Taylor \& Todd, 1995b; Venkatesh et al., 2003). FC was included as a direct determinant of BI and AU in many theories and by many researchers in the field of technology studies. For example, the relationship between FC and BI was found to be significant in several studies (e.g., Shih \& Fang, 2004; Yi et al., 2006). On the contrary, other researchers found FC non-significant in predicting BI but significant in determining usage (Chang et al., 2007; Limayem \& Hirt, 2000).

Thus, the importance of the external influence of facilitating conditions on the decision-making process is a crucial antecedent of human behavioural roles within information system studies (Shih \& Fang, 2004; Tarhini et al., 2016) and within the e-learning context (Ngai, Poon, \& Chan, 2007; Maldonado et al., 2009). Therefore, it is very important to investigate whether FC has a direct influence on the actual usage of the e-learning system, as the absences of facilitating resources may represent barriers to usage (Taylor \& Todd, 1995a, p. 153). Hence, it is expected that these external resources will lead the students to adopt the learning management systems. Based on the above discussion, the researcher proposes the following hypothesis.

H9: Facilitating conditions will have a positive influence on actual usage of web-based learning system.

\subsection{Behavioural Intention}

The presence of Behavioural Intention (BI) in TAM is one of the major differences with TRA. BI is considered to be an immediate antecedent of usage behaviour and gives an indication about an individuals' readiness to perform a specific behaviour. Ajzen (1991) claims that as a general rule, "the stronger the intention to engage in a behavior, the more likely should be its performance". In TAM, both PU and PEOU influence an individual's intention to use the technology, which in turns influence the usage behaviour (Davis, 1989).

There is considerable support in literature for the relationship between BI and usage behaviour in general (Davis et al., 1989; Taylor \& Todd, 1995a; Taylor \& Todd, 1995b; Venkatesh \& Davis, 2000; Venkatesh et al., 2003). This has recently been extended to the e-learning context (Tarhini, Hone, \& Liu, 2014c; Chang \& Tung, 2008; Masa'deh et al., 2015). In addition, the path from BI to AU is significant in the TAM, DTPB, and TPB and models. BI has a large influence on AU. However, it is worth mentioning that when individuals have prior experience with using the technology, the effect of BI is more predictive on AU (Taylor \& Todd, 1995b).

In the context of information system research, system usage were studied as a dependent variable and is often measured by only BI (Agarwal \& Karahanna, 2000; Venkatesh \& Morris, 2000; Gefen \& Straub, 2000), or by only AU (Szajna, 1994; Davis, 1989), or even both BI and AU (Venkatesh \& Davis, 2000; Venkatesh et al., 2003). In the context of e-learning and similar to previous studies, this research considered both BI and AU as dependent variables in the theoretical framework. It is expected that BI will have a direct influence in predicting the usage behaviour of students to accept and use the web-based learning system in the future. Therefore, the researcher proposes the following hypotheses:

H10: Student's BI will have a positive effect on his or her actual use of web-based learning system.

\subsection{Gender}

Gender is defined as a hierarchical separation between women and men embedded in both social institution and social practices (Jackson \& Scott, 2001). The consideration of gender in models of behaviour was introduced in gender schema theory (Bem, 1981) and other technology acceptance models (e.g., TAM 2 and TPB). Previous studies has shown that men and woman are different in decision-making processes and usually use different socially constructed cognitive structures (Venkatesh \& Morris, 2000). 
Previous research has suggested that gender plays an important role in predicting usage behaviour in the domain of IS research (e.g., Venkatesh \& Morris, 2000; Gefen \& Straub, 1997; Porter \& Donthu, 2006; Venkatesh et al., 2003; He \& Freeman, 2010; Wang, Wu, \& Wang, 2009; Morris \& Venkatesh, 2000; Tarhini et al., 2014). For example, Venkatesh et al. (2003) found that the explanatory power of TAM significantly increased to $52 \%$ after the inclusion of gender as a moderator. More specifically, gender was found to have a moderating impact on the relationships between PU, PEOU, SE, SN, QWL and BI as well as AU.

Venkatesh et al. (2003) found gender to influence the relationship between performance expectancy (similar to PU) and BI, with the relationship significantly stronger for men compared to women. Their findings are consistent with literature in social psychology, which emphasizes that men are more pragmatic compared to women and highly task-oriented (Minton, Schneider, \& Wrightsman, 1980). It is also argued that men usually have a greater emphasis on earnings and motivated by achievement needs (Hoffmann, 1980; Hofstede \& Hofstede, 2005) which is directly related to usefulness perceptions. This suggests that men place a higher importance on the usefulness of the system. Their argument is also supported by other researchers (e.g., Srite \& Karahanna, 2006; Venkatesh \& Morris, 2000; Terzis \& Economides, 2011). In contrast, Wang et al. (2009) did not find any moderating effect of gender on the relationship between performance expectancy (similar to PU), effort expectancy (similar to PEOU) and BI. It is expected that gender will also affect the relationship between QWL and BI since it focuses on the benefits of the technology and this is considered a more salient issue for males than females (Kripanont, 2007).

In terms of the moderating impact of gender on the relationship between PEOU, SE, FC, SN and BI, it is expected to be stronger for women compared to men. Venkatesh et al. (2003) reported that the intention to adopt and use a system is more highly affected by effort expectancy for women than men. Their results are consistent with gender role studies (Lynott \& McCandless, 2000; Schumacher \& Morahan-Martin, 2001). The reason could be that women compared to men generally have higher computer anxiety and lower computer Self-Efficacy (SE). The difference is based on the correlational relationship which is closely related to PEOU, so that higher computer self-efficacy will lead to lowering of the importance of ease of use perception (Venkatesh \& Morris, 2000). This is also supported in previous research in psychology (e.g., Cooper \& Weaver, 2003; Roca et al., 2006) which suggests that men perceive analytical and competitive approaches to solving problems which will lead to higher score on Self-Efficacy (Venkatesh et al., 2004). Furthermore, it is expected that gender will have an impact on Facilitating Conditions (FC) and that the relationship will be stronger for women compared to men. This argument is based on Hofstede's cultural theory (Hofstede \& Hofstede, 2005) proposition and more specifically related to masculinity/femininity cultural dimensions, which indicates that women compared with men rated a higher importance towards FCs with respect to service aspects and the working environment. Additionally, it has been found that gender affects the relationship between SN and BI such that the effect is stronger for women (Venkatesh \& Morris, 2000; Venkatesh et al., 2003; Kripanont, 2007; Huang, Hood, \& Yoo, 2012). Women are found to rely more than men on others' opinion (Venkatesh \& Morris, 2000; Hofstede \& Hofstede, 2005) as they have a greater awareness of others' feelings compared to men and therefore more easily motivated by social pressure and affiliation needs than men. Therefore it is expected that the relationship between SN and BI will be stronger for women than for men (Wang et al., 2009).

In line with previous discussion, it is expected that the relationship between PU, QWL and BI will be stronger for male students, whereas the relationship between PEOU, SE, FC, SN and BI will be stronger for female students. Thus we propose the following hypotheses:

H11: a1, a2, a3, a4, a5, a6: The relationship between PEOU, PU, SN, QWL, SE, FC and Behavioural Intention and actual usage of the e-learning system will be moderated by the gender.

\subsection{Age}

Research has shown that age is an important demographic variable that has direct and moderating effects on behavioural intention, adoption and acceptance of technology (e.g., Chung et al., 2010; Venkatesh et al., 2003; Wang et al., 2009; McCoy, Everard, \& Jones, 2005; Yousafzai, Foxall, \& Pallister, 2007b; King \& He, 2006; Walker \& Johnson, 2008; Sun \& Zhang, 2006; Akhter, 2003; Porter \& Donthu, 2006). Venkatesh et al. (2003) reported that age was an important moderator within his UTAUT model. They found that within an organizational context, the relationships between performance expectancy (similar to PU), FC and BI was stronger for younger employees, while the relationship between effort expectancy (similar to PEOU) and SN was stronger for older employees in accepting and using the technology (Venkatesh et al., 2003). They concluded that "increased age has been shown to be associated with difficulty in processing complex stimuli and allocating attention to information on the job" (Venkatesh et al., 2003, p. 450). They also found that age moderate the 
relationship between facilitating conditions and behavioural intention. Similarly, Morris and Venkatesh (2000) found the same moderating effects of age. It could be that age increased the positive effect of SN due to greater need of affiliation (e.g., Morris \& Venkatesh, 2000; Burton-Jones \& Hubona, 2006).

In contrast with this, Chung et al. (2010) did not find any moderating effect of age on the relationship between PEOU, PU and BI in online communities. In sharp contrast, Wang et al. (2009) found that age differences moderate the relationship between effort expectancy (similar to PU) and BI and was stronger for older adults but did not find any moderating effect of age on effort expectancy (similar to PEOU) and BI. Sun and Zhang (2006) found that the relationship between PU and BI was stronger for younger adults in the adoption decision. Correspondingly and since QWL may be correlated with PU since its perceived the importance of technology on user's quality of work life, it is expected that the relationship between QWL and BI will be stronger for younger users. Additionally, with respect to social and psychological influence on the adoption decision, Jones et al. (2009) found the relationship between SN and BI to be stronger for older adults. Similarly, Wang et al. (2009) found that age moderates the relationship between $\mathrm{SN}$ and $\mathrm{BI}$, and the effect was stronger for older adults on using m-learning technology.

In terms of computer and internet self-efficacy, it was found that older people have low self-efficacy in use of technology (Czaja et al., 2006). The rationale could be that older adults often think that they are too old to learn a new technology (Turner, Turner, \& Van de Walle, 2007; Tarhini, 2013). Previous research also found that age differences influence the perceived difficulty of learning a new software application (Morris, Venkatesh, \& Ackerman, 2005; Morris \& Venkatesh, 2000). There is a clear evident that younger adults have lower levels of computer anxiety than their older counterparts (Chaffin \& Harlow, 2005; Saunders, 2004) and that lower levels of computer anxiety are associated with lesser reluctance to engage in opportunities to learn new Internet skills (Jung et al., 2010).

Despite the inconsistencies that have been found in previous research about the direct or moderating effect of Age on the influence of various determinants on behavioural intention, many researchers support the important role that age plays in the context of technology acceptance. Therefore, it is expected that the effect of age on the relationship between PEOU, SE, SN and BI will be stronger for older students, while the influence of PU, QWL on BI will be stronger for younger students. Therefore, we propose the following hypotheses:

H12: a1, a2, a3, a4, a5, a6: The relationship between PEOU, PU, SN, QWL, SE, FC and Behavioural Intention and actual usage of the e-learning system will be moderated by the age.

\subsection{Educational Level}

In previous studies, education level was related to knowledge and skills which in turns affect the behavioural beliefs (PU and PEOU) towards acceptance and usage of new technologies (Rogers, 2003; Agarwal \& Prasad, 1999). Educational level, like other individual factors, has been studied as an antecedent of PU or PEOU (Agarwal \& Prasad, 1999) and as a moderator that affects the relationship between main determinates and behavioural intention (Burton-Jones \& Hubona, 2006). In particular, educational level was found to influence the relationships between PEOU, PU, SN and BI (Porter \& Donthu, 2006; Rogers, 2003; Sun \& Zhang, 2006; Zakaria, 2001; Mahmood, Hall, \& Swanberg, 2001; Burton-Jones \& Hubona, 2006).

Venkatesh et al. (2000) found a positive correlation between the level of education and PU, Similarly, Burton-Jones and Hubona (2006) suggested that higher education level leads to positive association with PU and those users are less sensitive to PEOU since it will reduce the computer anxiety and improve the overall attitude. In contrast, Agarwal and Prasad (1999) found that there was no relationship between educational level and PU, but there was with PEOU. Similarly, Al-Gahtani (2008) found that educational level only moderate the influence of PEOU on BI, while no moderating impact were found on the relationship between PU and BI towards using computer applications on a voluntary basis in the context of Arab countries. Abu-Shanab (2011) found a moderating effect of educational level on the relationship between most of the key determinants of UTAUT and acceptance of internet banking in Jordan. Moreover, educational level was also found to negatively affect the social influence on behaviour when adopting new technology in an organization as both education and experience will empower the users (Burton-Jones \& Hubona, 2006; Lymperopoulos \& Chaniotakis, 2005).

The moderating impact of educational level on the relationship between quality of life and behavioural intention has not been investigated in literature. Nevertheless, it is expected that educational level will have an impact on the relationship between QWL and BI such that the relationship will be stronger for students with higher educational level. The rationale is that students who have higher level of education will perceive the e-learning system and value the impact of this system on their career. 
Despite mixed results, however the moderating role that educational level can play on the adoption and acceptance of technology is indisputable (see meta-analysis of Mahmood et al. (2001) and Sun and Zhang (2006)). Hence, it is expected that the relationships between (PU, QWL) and BI will be stronger for users with higher educational level, while the relationships between (SN, PEOU) will be stronger for users with lower educational level. We thus propose the following hypotheses:

H13: a1, a2, a3, a4, a5, a6: The relationship between PEOU, PU, SN, QWL, SE, FC and Behavioural Intention and actual usage of the e-learning system will be moderated by Educational Level.

\subsection{Experience}

The concept of experience refers to the involvement of an individual in something over a period of time. In the technology context, an individuals' experience is measured by the level of experience and number of years in using a specific technology and will result in a stronger and more stable behavioural intention relationship (Venkatesh \& Morris, 2000; Venkatesh et al., 2003; Poon, 2007). Users may employ the knowledge that have gained from their prior experience to form their intentions (Fishbein \& Ajzen, 1975). Experience was not incorporated in the original TPB and DTPB; however it was added later after follow-on studies due to its importance on the intentions (Morris \& Venkatesh, 2000). Moreover, TAM2 clearly incorporated Experience as a moderator that affects the relationship between main determinants and behavioural intention (Venkatesh \& Davis, 2000).

Previous research has found that a user's degree of relevant experience moderates a number of relationships within TAM (e.g., Lymperopoulos \& Chaniotakis, 2005; Al-Jabri \& Al-Khaldi, 1997; Venkatesh et al., 2003; Venkatesh \& Bala, 2008). The relationship between behavioural intention and usage was empirically confirmed to be more statistically significant for expert users compared to novice users (Taylor \& Todd, 1995a; Venkatesh et al., 2004; Venkatesh \& Davis, 2000) and thus experience will have a positive influence on the strength of the relationship between $\mathrm{BI}$ and $\mathrm{AU}$.

As for PU, Taylor and Todd (1995a) reported that experience significantly moderates the relationship of PU and BI such that the relationship was stronger for inexperienced users, their results were not expected. This means that experienced users tended to give less consideration on PU and based their consideration to control information in formation their intentions (Taylor \& Todd, 1995a). In contrast, Venkatesh et al. (2003) did not find a significant moderating effect of experience on the relationship between "performance expectancy" (similar to $\mathrm{PU})$ on BI. This suggested that PU has a strong impact on BI for inexperienced users.

Additionally, the moderating effect of experience on the relationship between PEOU and BI is clear and stable in the literature (Venkatesh \& Davis, 2000; Venkatesh \& Morris, 2000). Generally speaking, when users have prior knowledge in using the technology, this will provide the users a more robust base to learn as users will relate their incoming information with what they already know (Venkatesh et al., 2003). In other words, experienced users will perceive PEOU as not a big issue when learning a new technology (Venkatesh et al., 2003). Venkatesh (2002) found that the direct influence of PEOU on BU will decrease over time due to the experience that individuals obtain during the time using the system. In contrast, inexperienced users with no prior knowledge will prefer to use the technology which is easy to use.

With respect to $\mathrm{SN}$, empirical evidence has demonstrated that experience was also found to significantly moderate the relationship between SN on BI (Venkatesh \& Davis, 2000; Venkatesh \& Morris, 2000). Venkatesh and Davis (2000) argued that the influence of SN on BI will decrease over time. Where users already have extensive experience, the role of SN will be expected to be lower as users are more able to draw on their own past experiences to shape their perception rather than the opinions of others (Venkatesh \& Davis, 2000; Venkatesh \& Morris, 2000). Similarly, Karahanna, Straub and Chervany (1999) found that inexperienced users are more driven by SN than experienced users. It is expected that the relationship will be stronger for inexperienced users since they will be more sensitive to their colleagues' opinion (Venkatesh et al., 2003).

In terms of self-efficacy and facilitating conditions, it is noteworthy to mention that SE has been studied as a direct determinant and moderators on behavioural intention and usage behaviour to use the technology and is similar to "indirect" experience e.g. (Park et al., 2012; Vijayasarathy, 2004; Ong \& Lai, 2006; Roca et al., 2006). In addition, experience was found to influence the relationship between facilitating conditions and behavioural intention (Venkatesh et al., 2003). The authors found that the relationship was stronger for experience. They suggested that when the experience increases, this will lead to user's wider options for help and support and this will lead to more usage of the system. 
Therefore, it is expected that experience will play an important role on the relationship between main determinants and behavioural intention to use the e-learning system. It is expected that when students experience increases; they will be more aware of the benefits of the e-learning system on their education e.g. (Evanschitzky \& Wunderlich, 2006; Stoel \& Lee, 2003). Hence, we propose the following hypotheses:

H14: a1, a2, a3, a4, a5, a6: The relationship between PEOU, PU, SN, QWL, SE, FC and Behavioural Intention and actual usage of the e-learning system will be moderated by Experience.

\section{Discussion}

This paper proposed a theoretical framework that might be helpful in understanding the various factors that are expected to influence the adoption and acceptance of e-learning systems in the context of developing and developed countries in the context of higher educational institutions. The research model is based on prominent well known technology acceptance models and theories that have been previously well-validated, e.g., TAM, TAM2, TRA, DTPB and UTAUT which are relevant to the context of e-learning. These factors reflect personal, social, and situational factors and specifically include social norm, facilitating conditions, e-learning self-efficacy, quality of work life, perceived ease of use, perceived usefulness and behavioural intention and usage. In addition, demographic characteristics were integrated as a set of moderators in the model.

Therefore this research proposes and tests two types of hypotheses, in the first category, this study proposes 10 direct hypotheses from $\mathrm{H} 1$ to H10. In the second category, 4 individual characteristics were hypothesized to have a moderating impact on the relationship between the main determinants and BI. It is expected that extending the TAM to include SN, SE, QWL and FC, in addition to the sets of individual characteristics as moderators, may help in explaining more of the variance of behavioural intention and actual usage as well as explore reasons for why the model may hold better in some contexts than others.

\section{References}

Abbasi, M. S., Hassouna, M., \& Shah, F. (2015). Social, Organizational, Demography and Individuals' Technology Acceptance Behaviour: A Conceptual Model. European Scientific Journal, 11(9), $48-76$.

Abbasi, M. S., Tarhini, A., Elyas, T., \& Shah, F. (2015). Impact of individualism and collectivism over the individual's technology acceptance behaviour: A multi-group analysis between Pakistan and Turkey. $\begin{array}{llll}\text { Journal of Enterprise Information } & \text { Management, 28(6), }\end{array}$ http://dx.doi.org/10.1108/JEIM-12-2014-0124

Abdullah, F., \& Ward, R. (2016). Developing a General Extended Technology Acceptance Model for E-Learning (GETAMEL) by analysing commonly used external factors. Computers in Human Behavior, 56, 238-256. http://dx.doi.org/10.1016/j.chb.2015.11.036

Abdullah, F., Ward, R., \& Ahmed, E. (2016). Investigating the influence of the most commonly used external variables of TAM on students' Perceived Ease of Use (PEOU) and Perceived Usefulness (PU) of e-portfolios. Computers in Human Behavior, 63, 75-90. http://dx.doi.org/10.1016/j.chb.2016.05.014

Abu-Shanab, E. A. (2011, March). Education level as a technology adoption moderator. In Computer Research and Development (ICCRD), 2011 3rd International Conference on (Vol. 1, pp. 324-328). IEEE. http://dx.doi.org/10.1109/iccrd.2011.5764029

Abu-Shanab, E., Momani, A., \& Ababneh, N. (2012, April 25-27). Teachers' Adoption Of E-learning Systems: The Case of EduWave in Jordan. The 2012 International Arab Conference of E-Technology (IACe-T'2012), Zarqa, Jordan (pp. 51-56).

Abu-Shanab, E. (2014). E-Learning System's Acceptance: A Comparative Study. International Journal of Web-Based Learning and Teaching Technologies (IJWLTT), 9(4), 1-13. http://dx.doi.org/10.4018/ijwltt.2014100101

Agarwal, R., \& Karahanna, E. (2000). Time flies when you're having fun: Cognitive absorption and beliefs about information technology usage. MIS quarterly, 24(4), 665-694. http://dx.doi.org/10.2307/3250951

Agarwal, R., \& Prasad, J. (1999). Are individual differences germane to the acceptance of new information technologies? Decision Sciences, 30(2), 361-391. http://dx.doi.org/10.1111/j.1540-5915.1999.tb01614.x

Ajjan, H., \& Hartshorne, R. (2008). Investigating faculty decisions to adopt Web 2.0 technologies: Theory and empirical tests. The Internet and Higher Education, 11(2), 71-80. http://dx.doi.org/10.1016/j.iheduc.2008.05.002 
Ajzen, I. (1985). From intentions to actions: A theory of planned behavior. In Action control (pp. 11-39). Springer Berlin Heidelberg. http://dx.doi.org/10.1007/978-3-642-69746-3_2

Ajzen, I. (1991). The theory of planned behavior. Organizational Behavior and Human Decision Processes, 50(2), 179-211. http://dx.doi.org/10.1016/0749-5978(91)90020-T

Akhter, S. H. (2003). Digital divide and purchase intention: Why demographic psychology matters. Journal of Economic Psychology, 24(3), 321-327. http://dx.doi.org/10.1016/S0167-4870(02)00171-X

Alalwan, A. A., Dwivedi, Y., Rana, N. P., \& Williams, M. D. (2016). Consumer adoption of mobile banking in Jordan: Examining the role of usefulness, ease of use, perceived risk and self-efficacy. Journal of Enterprise Information Management, 29(1), 118-139. http://dx.doi.org/10.1108/JEIM-04-2015-0035

Alalwan, A. A., Dwivedi, Y. K., \& Williams, M. D. (2016). Customers' Intention and Adoption of Telebanking in Jordan. Information Systems Management, 33(2), 154-178.

Alalwan, A. A., Dwivedi, Y. K., Rana, N. P., Lal, B., \& Williams, M. D. (2015). Consumer adoption of Internet banking in Jordan: Examining the role of hedonic motivation, habit, self-efficacy and trust. Journal of Financial Services Marketing, 20(2), 145-157. http://dx.doi.org/10.1057/fsm.2015.5

Alenezi, H., Tarhini, A., \& Sharma, S. K. (2015). Development of a Quantitative Model to Investigate the Strategic Relationship between Information Quality and E-Government Benefits. Transforming Government: People, Process and Policy, 9(3), 324-351. http://dx.doi.org/10.1108/TG-01-2015-0004

Alenezi, H., Tarhini, A., \& Masa'deh, R. (2015a). Investigating the Strategic Relationship between Information Quality and E-Government Benefits: A Literature Review. International Review of Social Sciences and Humanities, 9(1), 33-50

Alenezi, H., Tarhini, A., \& Masa'deh, R. (2015b). Exploring the relationship between information quality and E-government benefits: A literature review. International Review of Social Science and Humanities, 9(1), 69-78.

Al-Gahtani, S. S. (2008). Testing for the applicability of the TAM model in the Arabic context: Exploring an extended TAM with three moderating factors. Information Resources Management Journal (IRMJ), 21(1), 1-26. http://dx.doi.org/10.4018/irmj.2008100101

Al-Jabri, I. M., \& Al-Khaldi, M. A. (1997). Effects of user characteristics on computer attitudes among undergraduate business students. Journal of Organizational and End User Computing (JOEUC), 9(2), 16-23. http://dx.doi.org/10.4018/joeuc. 1997040102

Almajali, D. A., Masa'deh, R., \& Tarhini, A. (2016). Antecedents of ERP Systems Implementation Success: A Study on Jordanian Healthcare Sector. Journal of Enterprise Information Management, 29(4), 549-565. http://dx.doi.org/10.1108/JEIM-03-2015-0024

Almajali, D., Masa'deh, R., \& Al-Lozi, M. (2016). Determinants of the Actual Use of E-Learning Systems: An Empirical Study on Zarqa University in Jordan. Journal of Social Sciences, 5(2), 172-200.

Altamony, H., Tarhini, A., Al-Salti, Z., Gharaibeh, A., \& Elyas, T. (2016). The relationship between Change Management Strategy and Successful Enterprise Resource Planning (ERP) Implementations: A Theoretical Perspective. International Journal of Business Management and Economic Research, 7(4), 690-703.

Álvarez, A., Martín, M., Fernández-Castro, I., \& Urretavizcaya, M. (2013). Blending traditional teaching methods with learning environments: Experience, cyclical evaluation process and impact with MAgAdI. Computers \& Education, 68, 129-140. http://dx.doi.org/10.1016/j.compedu.2013.05.006

Anormaliza, R., Ivan, R., Sabaté i Garriga, F., \& Guevara Viejo, F. (2015). Evaluating student acceptance level of e-learning systems. In ICERI2015: Proceedings 8th International Conference of Education, Research and Innovation (pp. 2393-2399). Seville, Spain.

Aparicio, M., Bacao, F., \& Oliveira, T. (2016). Cultural impacts on e-learning systems' success. The Internet and Higher Education. http://dx.doi.org/10.1016/j.iheduc.2016.06.003

Bagozzi, R. P. (2007). The Legacy of the Technology Acceptance Model and a Proposal for a Paradigm Shift. Journal of the Association for Information Systems, 8(4), 244-254.

Bandura, A. (1995). Self-efficacy in changing societies. London, UK: Cambridge University Press. http://dx.doi.org/10.1017/CBO9780511527692

Bandura, A. (1997). Self-Efficacy: The Exercise of Control (p. 604). New York, W.H. Freeman. 
Bem, S. L. (1981). The BSRI and gender schema theory: A reply to Spence and Helmreich. Psychological Review, 88(4), 369-371. http://dx.doi.org/10.1037/0033-295X.88.4.369

Burton-Jones, A., \& Hubona, G. S. (2006). The mediation of external variables in the technology acceptance model. Information \& Management, 43(6), 706-717. http://dx.doi.org/10.1016/j.im.2006.03.007

Cascio, W. F., \& McEvoy, G. (2003) Managing human resources: Productivity, quality of work life, profits. Personnel Psychology, 51(4), 1041-1044.

Chaffin, A. J., \& Harlow, S. D. (2005). Cognitive learning applied to older adult learners and technology. Educational Gerontology, 31(4), 301-329. http://dx.doi.org/10.1080/03601270590916803

Chang, I., Hwang, H. G., Hung, W. F., \& Li, Y. C. (2007). Physicians' acceptance of pharmacokinetics-based clinical decision support systems. Expert Systems with Applications, 33(2), 296-303. http://dx.doi.org/10.1016/j.eswa.2006.05.001

Chang, S. C., \& Tung, F. C. (2008). An empirical investigation of students' behavioural intentions to use the online learning course websites. British Journal of Educational Technology, 39(1), 71-83.

Chatzoglou, P. D., Sarigiannidis, L., Vraimaki, E., \& Diamantidis, A. (2009). Investigating Greek employees' intention to use web-based training. Computers \& Education, 53(3), 877-889. http://dx.doi.org/10.1016/j.compedu.2009.05.007

Chau, P. Y. K., \& Hu, P. J. (2002). Examining a model of information technology acceptance by individual professionals: An exploratory study. Journal of management information systems, 18(4), 191-230.

Chesney, T. (2006). An acceptance model for useful and fun information systems. Human Technology: An Interdisciplinary Journal on Humans in ICT Environments, 2(2), 225-235. http://dx.doi.org/10.17011/ht/urn.2006520

Chung, J. E., Park, N., Wang, H., Fulk, J., \& McLaughlin, M. (2010). Age differences in perceptions of online community participation among non-users: An extension of the Technology Acceptance Model. Computers in Human Behavior, 26(6), 1674-1684. http://dx.doi.org/10.1016/j.chb.2010.06.016

Compeau, D. R., \& Higgins, C. A. (1995). Computer self-efficacy: Development of a measure and initial test. MIS quarterly, 19(2), 189-211. http://dx.doi.org/10.2307/249688

Cooper, J., \& Weaver, K. D. (2003). Gender and computers: Understanding the digital divide. Mahwah, NJ: Lawrence Erlbaum Associates.

Czaja, S. J., Charness, N., Fisk, A. D., Hertzog, C., Nair, S. N., Rogers, W. A., \& Sharit, J. (2006). Factors predicting the use of technology: Findings from the Center for Research and Education on Aging and Technology Enhancement (CREATE). Psychology and aging, 21(2), 333-352. http://dx.doi.org/10.1037/0882-7974.21.2.333

Darawsheh, S., ALshaar, A., Masa'deh, R., \& AL-Lozi, M. (2016). The degree of heads of departments at the University of Dammam to practice transformational leadership style from the point of view of the faculty members. Journal of Social Sciences, 5(1), 56-79.

Davis, F. D. (1989). Perceived usefulness, perceived ease of use, and user acceptance of information technology. MIS quarterly, 13(3), 319-340. http://dx.doi.org/10.2307/249008

Davis, F. D., Bagozzi, R. P., \& Warshaw, P. R. (1989). User acceptance of computer technology: A comparison of two theoretical models. Management Science, 35(8), 982-1003. http://dx.doi.org/10.1287/mnsc.35.8.982

Deng, L., \& Tavares, N. J. (2013). From Moodle to Facebook: Exploring students' motivation and experiences in online communities. Computers \& Education, 68(6), 167-176. http://dx.doi.org/10.1016/j.compedu.2013.04.028

Downey, J. (2006). Measuring general computer self-efficacy: The surprising comparison of three instruments in predicting performance, attitudes, and usage. In Proceedings of the 39th Annual Hawaii International Conference on System Science. IEEE. http://dx.doi.org/10.1109/HICSS.2006.268

El-Masri, M., \& Tarhini, A. (2015). A Design Science Approach to Gamify Education: From Games to Platforms. In Twenty-Third European Conference on Information Systems (ECIS) (pp. 26-38). Münster, German.

Esterhuyse, M., \& Scholtz, B. (2015). Barriers to E-Learning in a Developing Country: An Explorative Study. In Proceedings of the 9th IDIA conference. Nungwi, Zanzibar. 
Esterhuyse, M., \& Scholtz, B. (2016). The Intention to Use E-Learning in Corporations. In Proceedings of the 2nd International Conference on Information Resources Management (pp. 3-18). Cape Town, South Africa.

Evanschitzky, H., \& Wunderlich, M. (2006). An examination of moderator effects in the four-stage loyalty model. Journal of Service Research, 8(4), 330-345. http://dx.doi.org/10.1177/1094670506286325

Fishbein, M., \& Ajzen, I. (1975). Belief, attitude, intention and behavior: An introduction to theory and research. Reading, MA: Addison-Wesley Publishing Company.

Fu, J. R., Farn, C. K., \& Chao, W. P. (2006). Acceptance of electronic tax filing: A study of taxpayer intentions. Information \& Management, 43(1), 109-126. http://dx.doi.org/10.1016/j.im.2005.04.001

Gefen, D., \& Straub, D. W. (1997). Gender differences in the perception and use of e-mail: An extension to the technology acceptance model. MIS quarterly, 21(4), 389-400. http://dx.doi.org/10.2307/249720

Gefen, D., \& Straub, D. W. (2000). The Relative Importance of Perceived Ease of Use in IS Adoption: A Study of E-Commerce Adoption. Journal of the association for Information Systems, 1(1), 1-18.

Guo, Y., \& Barnes, S. (2007). Why people buy virtual items in virtual worlds with real money. ACM SIGMIS Database, 38(4), 69-76. http://dx.doi.org/10.1145/1314234.1314247

Harb, Y., \& Abu-Shanab, E. (2009). E-learning Initiatives in Jordan: Pedagogical Evaluation of the Hashemite University E-learning System. In A case study presented in the Proceedings of the 3rd Mosharaka International Conference on Communications, Networking and Information Technology (pp. 21-23). Amman, Jordan.

Hassouna, M., Elyas, T., \& Abou Trab, M. S. (2015). Customer Churn in Mobile Markets: A Comparison of Techniques. International Business Research, 8(6), 224-237. http://dx.doi.org/10.5539/ibr.v8n6p224

He, J., \& Freeman, L. A. (2010). Are men more technology-oriented than women? The role of gender on the development of general computer self-efficacy of college students. Journal of Information Systems Education, 21(2), 203-212.

Hernandez, B., Jimenez, J., \& Jose Martin, M. (2009). The impact of self-efficacy, ease of use and usefulness on e-purchasing: An analysis of experienced e-shoppers. Interacting with Computers, 21(1), 146-156. http://dx.doi.org/10.1016/j.intcom.2008.11.001

Hoffmann, L. W. (1980). Early childhood experiences and women's achievement motives. Journal of Social Issues, 28(2), 129-155. http://dx.doi.org/10.1111/j.1540-4560.1972.tb00022.x

Hofstede, G., \& Hofstede, J. (2005). Cultures and Organizations: Software of the Mind. London, McGraw-Hill.

Huang, W. H. D., Hood, D. W., \& Yoo, S. J. (2012). Gender divide and acceptance of collaborative Web 2.0 applications for learning in higher education. The Internet and Higher Education, 16(1), 57-65.

Igbaria, M., Parasuraman, S., \& Baroudi, J. J. (1996). A motivational model of microcomputer usage. Journal of management information systems, 13(1), 127-143. http://dx.doi.org/10.1080/07421222.1996.11518115

Igbaria, M., Zinatelli, N., Cragg, P., \& Cavaye, A. L. (1997). Personal computing acceptance factors in small firms: A structural equation model. MIS quarterly, 21(3), 279-305. http://dx.doi.org/10.2307/249498

Islam, A. (2013). Investigating e-learning system usage outcomes in the university context. Computers \& Education, 69(3), 387-399. http://dx.doi.org/10.1016/j.compedu.2013.07.037

Jackson, S., \& Scott, S. (2001). Putting the body's feet on the ground: Towards a sociological reconceptualization of gendered and sexual embodiment. In Constructing gendered bodies (pp. 9-24). Palgrave Macmillan, UK. http://dx.doi.org/10.1057/9780230294202_2

Jones, S., Fox, S., Internet, P., \& Project, A. L. (2009). Generations online in 2009. Pew Internet \& American Life Project. Washington, DC.

Jung, Y., Peng, W., Moran, M., Jin, S. A. A., McLaughlin, M., Cody, M., ... Silverstein, M. (2010). Low-income minority seniors' enrollment in a cybercafé: Psychological barriers to crossing the digital divide. Educational Gerontology, 36(3), 193-212. http://dx.doi.org/10.1080/03601270903183313

Karahanna, E., Straub, D. W., \& Chervany, N. L. (1999). Information technology adoption across time: A cross-sectional comparison of pre-adoption and post-adoption beliefs. MIS quarterly, 23(2), 183-213. http://dx.doi.org/10.2307/249751 
King, W. R., \& He, J. (2006). A meta-analysis of the technology acceptance model. Information \& Management, 43(6), 740-755. http://dx.doi.org/10.1016/j.im.2006.05.003

Kripanont, N. (2007). Examining a technology acceptance model of internet usage by academics within Thai business schools (Unpublished Doctoral Dissertation). Victoria University Melbourne, Australia.

Lam, P., Lo, J., Lee, J., \& McNaught, C. (2012). Evaluations of online learning activities based on LMS logs. Higher education institutions and learning management systems: Adoption and standardization, 2(1), 75-93. http://dx.doi.org/10.4018/978-1-60960-884-2.ch004

Lederer, A. L., Maupin, D. J., Sena, M. P., \& Zhuang, Y. (2000). The technology acceptance model and the $\begin{array}{lllll}\text { World Wide Web. Decision Support } & \text { Systems, 2892. }\end{array}$ http://dx.doi.org/10.1016/S0167-9236(00)00076-2

Lewis, W., Agarwal, R., \& Sambamurthy, V. (2003). Sources of influence on beliefs about information technology use: An empirical study of knowledge workers. MIS quarterly, 27(4), 657-678.

Liaw, S. S. (2008). Investigating students' perceived satisfaction, behavioral intention, and effectiveness of e-learning: A case study of the Blackboard system. Computers \& Education, 51(2), 864-873. http://dx.doi.org/10.1016/j.compedu.2007.09.005

Limayem, M., \& Hirt, S. G. (2000). Internet-based teaching: How to encourage university students to adopt advanced Internet-based technologies? In Proceedings of the 33rd Annual Hawaii International Conference on System Sciences, 2000 (p. 9). IEEE. http://dx.doi.org/10.1109/HICSS.2000.926640

Lin, H. F. (2006). Understanding behavioral intention to participate in virtual communities. CyberPsychology \& Behavior, 9(5), 540-547. http://dx.doi.org/10.1089/cpb.2006.9.540

Liu, I. F., Chen, M. C., Sun, Y. S., Wible, D., \& Kuo, C. H. (2010). Extending the TAM model to explore the factors that affect Intention to Use an Online Learning Community. Computers \& Education, 54(2), 600-610. http://dx.doi.org/10.1016/j.compedu.2009.09.009

Lymperopoulos, C., \& Chaniotakis, I. E. (2005). Factors affecting acceptance of the internet as a marketing-intelligence tool among employees of Greek bank branches. International Journal of Bank Marketing, 23(6), 484-505. http://dx.doi.org/10.1108/02652320510619602

Lynott, P. P., \& McCandless, N. J. (2000). The impact of age vs. life experience on the gender role attitudes of women in different cohorts. Journal of Women \& Aging, 12(2), 5-21. http://dx.doi.org/10.1300/J074v12n01_02

Mahmood, M. A., Hall, L., \& Swanberg, D. L. (2001). Factors affecting information technology usage: A meta-analysis of the empirical literature. Journal of Organizational Computing and Electronic Commerce, 11(2), 107-130. http://dx.doi.org/10.1207/S15327744JOCE1102_02

Maldonado, U. P. T., Khan, G. F., Moon, J., \& Rho, J. J. (2009). E-learning motivation, students' acceptance/use of educational portal in developing countries: A case study of Peru. In Fourth International Conference on Computer Sciences and Convergence Information Technology, 2009. ICCIT'09 (pp. 1431-1441). IEEE. http://dx.doi.org/10.1109/ICCIT.2009.77

Marakas, G. M., Mun, Y. Y., \& Johnson, R. D. (1998). The multilevel and multifaceted character of computer self-efficacy: Toward clarification of the construct and an integrative framework for research. Information systems research, 9(2), 126-163. http://dx.doi.org/10.1287/isre.9.2.126

Masa'deh, R., Tayeh, M., Al-Jarrah, I. M., \& Tarhini, A. (2015). Accounting vs. Market-based Measures of Firm Performance Related to Information Technology Investments. International Review of Social Sciences and Humanities, 9(1), 129-145.

Masa'deh, R., Gharaibeh, A., Tarhini, A., \& Obeidat, B. (2015). Knowledge Sharing Capability: A Literature Review. In Fourth Scientific \& Research Conference on New Trends in Business, Management and Social Sciences (pp. 1-16). Istanbul, Turkey. http://dx.doi.org/10.2139/ssrn.2696924

Masa'deh, R., Obeidat, B. Y., \& Al-Dmour, R. H. (2015). Knowledge Management Strategies as Intermediary Variables between IT-Business Strategic Alignment and Firm Performance. European Scientific Journal, 11(7), 344-368

Masa'deh, R., Tarhini, A., Al-Dmour, R. H., \& Obeidat, B. Y. (2015). Strategic IT-Business Alignment as Managers' Explorative and Exploitative Strategies. European Scientific Journal, 11(7), 437-457. 
Masa'deh, R., Obeidat, B. Y., \& Tarhini, A. (2016). A Jordanian Empirical Study of The Associations Among Transformational Leadership, Transactional Leadership, Knowledge Sharing, Job Performance, and Firm Performance: A Structural Equation Modelling Approach. Journal of Management Development, 35(5), 681-705. http://dx.doi.org/10.1108/JMD-09-2015-0134

Masa'deh, R., Tarhini, A., Mohammed, A. B., \& Maqableh, M. (2016). Modeling Factors Affecting Student's Usage Behaviour of E-Learning Systems in Lebanon. International Journal of Business and Management, 11(2), 299-312. http://dx.doi.org/10.5539/ijbm.v11n2p299

Masa'deh, R., Shannak, R., Maqableh, M., \& Tarhini, A. (2017). The Impact of Knowledge Management on Job Performance in Higher Education: The Case of the University of Jordan. Journal of Enterprise Information Management, 30(2), 13-37.

McCoy, S., Everard, A., \& Jones, B. (2005). An examination of the technology acceptance model in Uruguay and the U.S.: A focus on culture. Journal of Global Information Technology, 8(2), 27-45. http://dx.doi.org/10.1080/1097198X.2005.10856395

McGill, T. J., Klobas, J. E., \& Renzi, S. (2014). Critical success factors for the continuation of e-learning initiatives. The Internet and Higher Education, 22(3), 24-36. http://dx.doi.org/10.1016/j.iheduc.2014.04.001

Minton, H. L., Schneider, F. W., \& Wrightsman, L. S. (1980). Differential psychology. New York, NY, USA: Brooks/Cole Publishing Company.

Morris, M. G., \& Venkatesh, V. (2000). Age differences in technology adoption decisions: Implications for a $\begin{array}{llll}\text { changing work force. Personnel } & \text { 375-403. }\end{array}$ http://dx.doi.org/10.1111/j.1744-6570.2000.tb00206.x

Morris, M. G., Venkatesh, V., \& Ackerman, P. L. (2005). Gender and age differences in employee decisions about new technology: An extension to the theory of planned behavior. IEEE transactions on engineering management , 52(1), 69-84. http://dx.doi.org/10.1109/TEM.2004.839967

Ndubisi, N. (2006). Factors of online learning adoption: A comparative juxtaposition of the theory of planned behaviour and the technology acceptance model. International Journal on E-learning, 5(4), 571-591.

Ngai, E. W. T., Poon, J. K. L., \& Chan, Y. H. C. (2007). Empirical examination of the adoption of WebCT using TAM. Computers \& amp; Education, 48(2), 250-267. http://dx.doi.org/10.1016/j.compedu.2004.11.007

Obeidat, B. Y., Al-Suradi, M., Masa'deh, R., \& Tarhini, A. (2016). The Impact of Knowledge Management on Innovation: An Empirical Study on Jordanian Consultancy Firms. Management Research Review, 39(12), 33-52.

Orozco, J., Tarhini, A., Masa'deh, R., \& Tarhini, T. (2015). A framework of IS/business alignment management practices to improve the design of IT Governance architectures. International Journal of Business and Management, 10(4), 1-12. http://dx.doi.org/10.5539/ijbm.v10n4p1

Ong, C. S., \& Lai, J. Y. (2006). Gender differences in perceptions and relationships among dominants of e-learning acceptance. Computers in Human Behavior, 22(2), 816-829. http://dx.doi.org/10.1016/j.chb.2004.03.006

Park, S. Y. (2009). An analysis of the technology acceptance model in understanding university students' behavioral intention to use e-learning. Educational Technology \& Society, 12(1), 150-162.

Park, S. Y., Nam, M. W., \& Cha, S. B. (2012). University students' behavioral intention to use mobile learning: Evaluating the technology acceptance model. British Journal of Educational Technology, 43(4), 592-605. http://dx.doi.org/10.1111/j.1467-8535.2011.01229.x

Peng, H., Su, Y. J., Chou, C., \& Tsai, C. C. (2009). Ubiquitous knowledge construction: Mobile learning re-defined and a conceptual framework. Innovations in Education and Teaching International, 46(2), 171-183. http://dx.doi.org/10.1080/14703290902843828

Piña, A. A. (2010). An overview of learning management systems. Learning Management System Technologies and Software Solutions for On-line Teaching: Tools and Applications. Y. Kats. Pennsylvania, IGI Global.

Poon, W. C. (2007). Users' adoption of e-banking services: The Malaysian perspective. Journal of Business \& Industrial Marketing, 23(1), 59-69. http://dx.doi.org/10.1108/08858620810841498 
Porter, C. E., \& Donthu, N. (2006). Using the technology acceptance model to explain how attitudes determine Internet usage: The role of perceived access barriers and demographics. Journal of Business Research, 59(1), 999-1007. http://dx.doi.org/10.1016/j.jbusres.2006.06.003

Ramirez-Anormaliza, R., Sabate, F., \& Llinàs-Audet, X. (2016). The acceptance and use of the e-learning systems among the university teachers in Ecuador, In Proceedings of EDULEARN16 Conference (pp. 3666-3674). Barcelona, Spain.

Roca, J. C., Chiu, C. M., \& Martínez, F. J. (2006). Understanding e-learning continuance intention: An extension of the Technology Acceptance Model. International Journal of Human-Computer Studies, 64(2), 683-696. http://dx.doi.org/10.1016/j.ijhcs.2006.01.003

Rogers, E. M. (2003). Diffusion of innovations. New York, NY: Free Press.

Saeed, K. A., \& Abdinnour-Helm, S. (2008). Examining the effects of information system characteristics and perceived usefulness on post adoption usage of information systems. Information \& Management, 45(2), 376-386. http://dx.doi.org/10.1016/j.im.2008.06.002

Saunders, E. J. (2004). Maximizing computer use among the elderly in rural senior centers. Educational Gerontology, 30(7), 573-585. http://dx.doi.org/10.1080/03601270490466967

Schumacher, P., \& Morahan-Martin, J. (2001). Gender, Internet and computer attitudes and experiences. Computers in Human Behavior, 17, 95-110. http://dx.doi.org/10.1016/S0747-5632(00)00032-7

Scholtz, B., Calitz, A., \& Whale, A. (2014). Students' Perceptions of ERP e-Learning Material in a Blended Learning Environment. In SACLA (pp. 1-11). Port Elizabeth, South Africa.

Sekaran, U., \& Bougie, R. (2011). Research Methods for Business: A Skill Building Approach (5th ed.). Wiley India Pvt. Ltd.

Sharma, S. K., \& Chandel, J. K. (2013). Technology acceptance model for the use of learning through websites among students in Oman. International Arab Journal of E-Technology, 3(1), 44-49.

Sharma, S. K., Chandel, J. K., \& Govindaluri, M. S. (2014). Students' acceptance and satisfaction of learning through course websites. Education, Business and Society: Contemporary Middle Eastern Issues, 7(2/3), 152-166. http://dx.doi.org/10.1108/EBS-08-2013-0032

Shih, Y. Y., \& Fang, K. (2004). The use of a decomposed theory of planned behavior to study Internet banking in Taiwan. Internet Research, 14(1), 213-223. http://dx.doi.org/10.1108/10662240410542643

Srite, M., \& Karahanna, E. (2006). The role of espoused national cultural values in technology acceptance. MIS quarterly, 30(2), 679-704.

Srite, M., \& Karahnana, E. (1999). The influence of national culture on the acceptance and use of information technologies: An empirical study. In AMCIS 1999 Proceedings (P. 355). Milwaukee, Wisconsin, USA.

Stoel, L., \& Lee, K. H. (2003). Modeling the effect of experience on student acceptance of Web-based courseware. Internet Research, 13(2), 364-374. http://dx.doi.org/10.1108/10662240310501649

Sun, H., \& Zhang, P. (2006). The role of moderating factors in user technology acceptance. International Journal of Human-Computer Studies, 64(3), 53-78. http://dx.doi.org/10.1016/j.jhcs.2005.04.013

Szajna, B. (1994). Software evaluation and choice: Predictive validation of the technology acceptance instrument. MIS quarterly, 18(3), 319-324. http://dx.doi.org/10.2307/249621

Tarhini, A. (2013). The effects of individual-level culture and demographic characteristics on e-learning acceptance in Lebanon and England: A structural equation modeling approach (Unpublished doctoral dissertation). Brunel University London, Middlesex, UK.

Tarhini, A., Hone, K., \& Liu, X. (2013a). Factors Affecting Students' Acceptance of E-Learning Environments in Developing Countries: A Structural Equation Modeling Approach. International Journal of Information and Education Technology, 3(1), 54-59. http://dx.doi.org/10.7763/IJIET.2013.V3.233

Tarhini, A., Hone, K., \& Liu, X. (2013b). User acceptance towards web-based learning systems: Investigating the role of social, organizational and individual factors in European higher education. Procedia Computer Science, 17(1), 189-197. http://dx.doi.org/10.1016/j.procs.2013.05.026

Tarhini, A., Hone, K., \& Liu, X. (2013c). Extending the TAM to Empirically Investigate the Students' Behavioural Intention to Use E-Learning in Developing Countries. Science and Information Conference (IEEE), United Kingdom. 
Tarhini, A., Hone, K., \& Liu, X. (2014a). The effects of individual differences on e-learning users' behaviour in developing countries: A structural equation model. Computers in Human Behavior, 41(2), 153-163. http://dx.doi.org/10.1016/j.chb.2014.09.020

Tarhini, A., Hone, K., \& Liu, X. (2014b). Measuring the moderating effect of Gender and Age on e-learning Acceptance in England: A structural equation modeling approach for an extended Technology Acceptance Model. Journal of Educational Computing Research, 51(2), 163-184. http://dx.doi.org/10.2190/EC.51.2.b

Tarhini, A., Arachchilage, N. A. G., Masa'deh, R., \& Abbasi, M. S. (2015). A Critical Review of Theories and Models of Technology Adoption and Acceptance in Information System Research. International Journal of Technology Diffusion (IJTD), 6(4), 58-77. http://dx.doi.org/10.4018/IJTD.2015100104

Tarhini, A., Scott, M., Sharma, S., \& Abbasi, M. S. (2015). Differences in intention to use educational RSS feeds between Lebanese and British students: A multi-group analysis based on the technology acceptance model. Electronic Journal of e-Learning, 13(1), 14-29.

Tarhini, A., Hone, K., \& Liu, X. (2015). A cross-cultural examination of the impact of social, organisational and individual factors on educational technology acceptance between British and Lebanese university students. British Journal of Educational Technology, 46(4), 739-755. http://dx.doi.org/10.1111/bjet.12169

Tarhini, A., Teo, T., \& Tarhini, T. (2015). A cross-cultural validity of the E-learning Acceptance Measure (ElAM) in Lebanon and England: A confirmatory factor analysis. Education and Information Technologies. http://dx.doi.org/10.1007/s10639-015-9381-9

Tarhini, A., Hassouna, M., Abbasi, M.S., \& Orozco, J. (2015). Towards the Acceptance of RSS to Support Learning: An empirical study to validate the Technology Acceptance Model in Lebanon. Electronic Journal of e-Learning, 13(1), 30-41.

Tarhini, A., Mgbemena, C., AbouTrab, M.S., \& Masa'deh, R. (2015). User Adoption of Online Banking in Nigeria: A Qualitative study. Journal of Internet Banking and Commerce, 20(3), 1-8.

Tarhini, A., Ammar, H., Tarhini, T., \& Masa'deh, R. (2015). Analysis of the Critical Success Factors for Enterprise Resource Planning Implementation from Stakeholders' Perspective: A Systematic Review. International Business Research, 8(4), 25-40. http://dx.doi.org/10.5539/ibr.v8n4p25

Tarhini, A., El-Masri, M., Ali, M., \& Serrano, A. (2016). Extending the UTAUT model to understand the Customers' Acceptance and Use of Internet Banking in Lebanon: A Structural Equation Modeling Approach. Information Technology and People, 29(4), 23-38.

Tarhini, A., Hone, K., Liu, X., \& Tarhini, T. (2016). Examining the Moderating Effect of Individual-level Cultural values on Users' Acceptance of E-learning in Developing Countries: A Structural Equation Modeling of an extended Technology Acceptance Model. Interactive Learning Environments, 1-23. http://dx.doi.org/10.1080/10494820.2015.1122635

Taylor, S., \& Todd, P. (1995a). Assessing IT usage: The role of prior experience. MIS quarterly, 19(4), 561-570. http://dx.doi.org/10.2307/249633

Taylor, S., \& Todd, P. (1995b). Decomposition and crossover effects in the theory of planned behavior: A study of consumer adoption intentions. International Journal of Research in Marketing, 12(2), 137-155. http://dx.doi.org/10.1016/0167-8116(94)00019-K

Terzis, V., \& Economides, A. A. (2011). Computer based assessment: Gender differences in perceptions and acceptance. Computers in Human Behavior, 27(1), 2108-2122. http://dx.doi.org/10.1016/j.chb.2011.06.005

Turner, P., Turner, S., \& Van de Walle, G. (2007). How older people account for their experiences with interactive $\begin{array}{llll}\text { technology. Behaviour \& Information } & \text { 287-296. }\end{array}$ http://dx.doi.org/10.1080/01449290601173499

Van Raaij, E. M., \& Schepers, J. J. L. (2008). The acceptance and use of a virtual learning environment in China. Computers \& Education, 50(2), 838-852. http://dx.doi.org/10.1016/j.compedu.2006.09.001

Venkatesh, V., \& Bala, H. (2008). Technology acceptance model 3 and a research agenda on interventions. Decision Sciences, 39(2), 273-315. http://dx.doi.org/10.1111/j.1540-5915.2008.00192.x

Venkatesh, V., \& Davis, F. D. (2000). A theoretical extension of the technology acceptance model: Four $\begin{array}{lllll}\text { longitudinal field } & \text { studies. } & \text { Management } & \text { Science, } & 46(3),\end{array}$ http://dx.doi.org/10.1287/mnsc.46.2.186.11926 
Venkatesh, V., \& Morris, M. G. (2000). Why don't men ever stop to ask for directions? Gender, social influence, and their role in technology acceptance and usage behavior. MIS quarterly, 24(1), 115-139. http://dx.doi.org/10.2307/3250981

Venkatesh, V., Morris, M. G., \& Ackerman, P. L. (2000). A longitudinal field investigation of gender differences in individual technology adoption decision-making processes. Organizational Behavior and Human Decision Processes, 83(4), 33-60. http://dx.doi.org/10.1006/obhd.2000.2896

Venkatesh, V., Morris, M. G., Davis, G. B., \& Davis, F. D. (2003). User acceptance of information technology: Toward a unified view. MIS quarterly, 27(3), 425-478.

Venkatesh, V., Morris, M. G., Sykes, T. A., \& Ackerman, P. L. (2004). Individual reactions to new technologies in the workplace: The role of gender as a psychological construct. Journal of Applied Social Psychology, 34(1), 445-467. http://dx.doi.org/10.1111/j.1559-1816.2004.tb02556.x

Vijayasarathy, L. R. (2004). Predicting consumer intentions to use on-line shopping: The case for an augmented technology acceptance model. Information \& Management, 41(2), 747-762. http://dx.doi.org/10.1016/j.im.2003.08.011

Whale, A. M., Scholtz, B. M., \& Calitz, A. P. (2015). Components of E-Learning for Enterprise Systems' Education in Developing Countries. In Proceedings of the 9th IDIA conference (pp. 418-433). Nungwi, Zanzibar.

Walker, G., \& Johnson, N. (2008). Faculty intentions to use components for Web-enhanced instruction. International Journal on E-Learning, 7(1), 133-152.

Wang, Y. S., Wu, M. C., \& Wang, H. Y. (2009). Investigating the determinants and age and gender differences in the acceptance of mobile learning. British Journal of Educational Technology, 40(2), 92-118. http://dx.doi.org/10.1111/j.1467-8535.2007.00809.x

Yadav, R., Sharma, S. K., \& Tarhini, A. (2016). A multi-analytical approach to understand and predict the mobile commerce adoption. Journal of Enterprise and Information Management, 29(2), 222-237. http://dx.doi.org/10.1108/JEIM-04-2015-0034

Yi, M. Y., \& Hwang, Y. (2003). Predicting the use of web-based information systems: Self-efficacy, enjoyment, learning goal orientation, and the technology acceptance model. International Journal of Human-Computer Studies, 59(2), 431-449. http://dx.doi.org/10.1016/S1071-5819(03)00114-9

Yi, M. Y., Jackson, J. D., Park, J. S., \& Probst, J. C. (2006). Understanding information technology acceptance by individual professionals: Toward an integrative view. Information \& Management, 43(3), 350-363. http://dx.doi.org/10.1016/j.im.2005.08.006

Yousafzai, S. Y., Foxall, G. R., \& Pallister, J. G. (2007a). Technology acceptance: A meta-analysis of the TAM: Part 1. Journal of Modelling in Management, 2(3), 251-280. http://dx.doi.org/10.1108/17465660710834453

Yousafzai, S. Y., Foxall, G. R., \& Pallister, J. G. (2007b). Technology acceptance: A meta-analysis of the TAM: Part 2. Journal of Modelling in Management, 2(3), 281-304. http://dx.doi.org/10.1108/17465660710834462

Yuen, A. H. K., \& Ma, W. W. K. (2008). Exploring teacher acceptance of e-learning technology. Asia-Pacific Journal of Teacher Education, 36, 229-243. http://dx.doi.org/10.1080/13598660802232779

Zakaria, Z. (2001). Factors related to information technology implementation in the Malaysian Ministry of Education Polytechnics (Doctoral dissertation). Virginia Polytechnic Institute and State University.

Zhang, S., Zhao, J., \& Tan, W. (2008). Extending TAM for online learning systems: An intrinsic motivation $\begin{array}{llllll}\text { perspective. Tsinghua Science } \quad \& \quad \text { Technology, } & \text { 13(3), }\end{array}$ http://dx.doi.org/10.1016/S1007-0214(08)70050-6

\section{Copyrights}

Copyright for this article is retained by the author(s), with first publication rights granted to the journal.

This is an open-access article distributed under the terms and conditions of the Creative Commons Attribution license (http://creativecommons.org/licenses/by/3.0/). 